\title{
CLINICAL AND HISTOPATHOLOGICAL STUDIES ON THE LEPROSY OF THE LARYNX
}

\section{Part I. GLINICAL STUDIES ON THE LEPROSY OF THE LARYNX}

\author{
Yoshio YOSHIE \\ National Leprosarium Tama-Zenshoen (Director : Y. Hayashi)
}

\begin{abstract}
The author examined the upper respiratory tract of the leprosy in-patients of the National Leprosarium Tama- $\div$ enshoen during the period from 1938 to 1943 and al:o studied the histopathological changes of the autopsied cases of the leprosy of the larynx.

The monograph on the present author on "Leprosy of the Upper Respiratory Tract" was destroyed while under printing by the bombing of Tokyo in 1943. Reported in the following is a part of the above monograph.
\end{abstract}

The author investigated the leprosy of the larynx of 973 leprosy patients (lepromatous type 711 cases, tuberculoid type 129 cases and neural type 133 cases) in respects of the rate and the time of the involvement, the part of predilection, symptoms and course of the disease.

Out of the 711 lepromatous patients including L1. L2 and L3, 460 cases (64.7\%) presented the lesions of some form in the larynx and the rate of the involvement was $96.6 \%$ for the highly advanced cases.

Tuberculoid changes in the epiglottis of the larynx were noticed in 7 tuberculoid cases (5.4\%), one of which was confirmed to be free from tuberculosis on histopathological examination and animal experiment.

Paralysis of the laryngeal nerves was seen in 12 cases (9.0\%) of the neural leprosy.

The larynx was involved, in the majority of the cases, during the 10 years period from the onset of leprosy and 55\% of those occured within 6 years from the onset.

The initial lesion of the laryngeal involvement became manifest mostly in the epiglottis.

Initial symptoms revealed as the congestion and the swelling of the epiglottis, arytenoids or vocal cords, but lasted generally only for several months being followed by recession to almost normal condition. After this apparently quiescent period of years, characteristic infiltration and nodulation developed in successive steps. Thus, it is the characteristic of the course of leprosy to present acute or subacute phase and spontaneous recession alternatively.

Nodules were frequently observed to occur around the entrance of the larynx and in the advanced stage they were observed in rosary shape.

Sometimes, plaques surrounded with red halo were noted to occur symmetrically on the arytenoid on both sides and to ulcerate superficially with relative repidity.

Diffuse infiltrations occur in the epiglottis, arytenoid as well as in the false and vocal cord.

Infiltrated mucous membrane passes into dry and yellowing one and is covered with leukoplakia at the site of advanced hypertrophy.

Ulceration in the larynx was only observed in $9.4 \%$ of the total cases examined.

Scar formation and constriction take place at the site of infiltration resulting in many kinds of distortions. e. g. backward inclination and destruction of the epiglotis, stricture of the laryngeal tract.

Immobility of the cord rarely occurs in laryngeal leprosy, it develops the restriction of abduction of the cord as the result of the paralysis of $\mathrm{m}$. posticus and, in more advanced cases, the fixation in the cadaver position of the cord owing to the paralysis of the recurrent laryngeal nerve which inviies severe dispnoea. 
The author confirmed, on a number of autopsy cases, the involvement of superior laryngeal nerve in all cases and that of the inferior nerve commonly in severe cases of the laryngeal leprosy.

In view of the above mentioned findings, the laryngeal dispnoea of the lepromatous leprosy is believed to occur as the result of the highly advanced infiltration and the paralysis of recurrent nerve owing to the lepromatous involvement.

As regard to the course of the laryngeal leprosy, lepromatous involvement frequently occurs during the period from 3 to 6 years after onset of leprosy, continual huskiness develops further 3 to 6 years after and the laryngeal stridor develops additional 3 to 6 years later.

Nowadays, however, on account of chemotherapy, lepromatous involvement of the larynx is hardly noticed and although it may occur, it will be absorbed sooner or later without leaving any kind of disturbance.

\title{
喉頭癩の臨床的及び病理解剖学的研究
}

\section{第 1 編 臨 床 的 観 察}

\author{
国立療養所 多磨全生園（園長 林 芳信）
}

義 江 義 雄

（昭和 30 年 11 月 25 日受稿）

本論文は 1938 年から 1943 年の間比多否全生園に打い て行つた上気道瀨の研究の 1 部である。1944年にそれま での研究成績をまめて, “上気道瀨”として出版の予定 でめつたが，製本の途中で空軖のために焼失して目的を 達しえないま今日に及んでいる。

終戦後ブロミンの出現によつて瀨の症状ととにその経 過が一変して, 現在では臨床上喉頭瀨を診る機会がはな はだ少くなつてきている。この論文は現在の化学療法郕 の影響を受けない喉頭瀨の臨床と病理に関する知見でめ つて，近ごろの所見とは多少打もむきの異るものがある と思われるが，今後の瀨研究の参考資料ともなれば幸で める。

本研究は財団法人服部報公会, 学術研究会議, 文部省 科学研究費の禣助によつて行つたものであつて, こてに 夷心より感謝の意を表する次第でまる。

\section{1.まえがき}

喉頭の癩变化に関する臨床的所見と病理解剖学的知見 については，1885年 Virchow ${ }^{15}$ の報告があり，その後 de la Sota, Glück ${ }^{5)}$, Gerber ${ }^{4)}$, Dorendorf ${ }^{3)}$, Bergen-

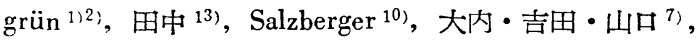
田尻 ${ }^{14}$, Pinkerton ${ }^{8 / 9)}$ 等によつて研究せられ, 臨床及び 病理解剖所見は大いに明かになつたが，な扔初期の変 化，臨床経過，発生病理などについては残された問題が
少くない。

本編に扏いては, 主として喉頭顆の初発变化とその後 に括ける症状及び経過について述べたい。

\section{2. 罪患率，罹患時期及び好発部位}

(a) 罹 患率

結節瀨 711 例について喉頭鏡㭘査で喉頭に瀬変化を認 めたものは, Table 1. の如く, 460例, 64.7\%で, 同時 に検查した鼻腔, 咽頭等の罹患率と比較すると, 同表に 示す如く, 罹患率の最も高い部位は鼻腔で, 次で喉頭, 口腔咽頭, 鼻咽腔の順でめる。喉頭の罹患率についての 先人の発表をみると, Gerber 70.3\%, Dorendorf 56.3\% Salzberger 90\%で, Bergengrün は結節瀨では早晚喉頭 が抢かされると述べている。わが国では田中は $61.5 \%$, 大内等 $64.6 \%$ ，田尻 $85.7 \%$ となつている。

この羅患率の差異は検査症例の全身病勢の軽重によつ て左右されると考えられるので，乙の点を検討しなけれ ば意義が少い。そとで私の検查した症例を全身の癩症状 によつて $\mathrm{L}_{1}, \mathrm{~L}_{2}, \mathrm{~L}_{3}$ に分けて, 喉頭の罹患率をみると, Table 2. の如くである。 $\mathrm{L}_{1}$ は皮虚の数力所に限局性の 軽度の浸潤乃至結節が見られるもの， $\mathrm{L}_{3}$ は強度の浸潤 及び多数の結節が全身の殆んど全域にひろがつているも の， $\mathrm{L}_{2}$ はとの中間のあのとした。従つて $\mathrm{L}_{1}$ の中にいす 
Table 1. Rate of the lepromatous involvement of the larynx and the other upper respiratory parts

\begin{tabular}{|c|c|c|c|c|c|}
\hline & Larynx & Nose & Nasopharynx & Pharynx \\
\hline \multicolumn{2}{|c|}{ Number of cases examined } & 711 & 734 & 645 & 727 \\
\hline \multicolumn{2}{|c|}{ Number of cases involved(\%) } & $460(64.7)$ & $684(93.2)$ & $3 \mathrm{I} 3(48.5)$ & $427(58.7)$ \\
\hline \multirow{3}{*}{ 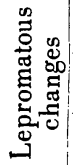 } & 1. Infiltration, Nodulation & $295(41.5)$ & $218(29.7)$ & $173(26.8)$ & $211(29.0)$ \\
\hline & 2. Ulceration & $43 \quad(6.0)$ & $156(21.3)$ & $23 \quad(3.6)$ & $68(9.3)$ \\
\hline & 3. Scar formation, Atrophy & $122(17.2)$ & $310(42.2)$ & $117(18.1)$ & $148(20.4)$ \\
\hline
\end{tabular}

Table 2. Relation between grade of the disease and involvement of the larynx

\begin{tabular}{|c|c|c|c|c|c|c|c|}
\hline \multirow{2}{*}{$\begin{array}{c}\text { Grade } \\
\text { of } \\
\text { disease }\end{array}$} & \multirow{2}{*}{$\begin{array}{c}\text { No. of } \\
\text { cases } \\
\text { examined }\end{array}$} & \multicolumn{4}{|c|}{ Lepromatous changes } & \multicolumn{2}{|c|}{ Rate of involvement } \\
\hline & & $\begin{array}{c}\text { Hyperaemia } \\
\text { Swelling }\end{array}$ & $\begin{array}{l}\text { Infiltration } \\
\text { Noduration }\end{array}$ & Ulceration & $\begin{array}{c}\text { Scar } \\
\text { Atrophy }\end{array}$ & $\begin{array}{c}\text { No. of } \\
\text { cases }\end{array}$ & $\%$ \\
\hline $\mathbf{L}_{1}$ & 102 & 7 & 13 & 0 & 2 & 22 & 21.6 \\
\hline $\mathrm{L}^{2}$ & 108 & 5 & 43 & 12 & 10 & 70 & 64.8 \\
\hline $\mathrm{L}_{3}$ & 118 & 0 & 31 & 18 & 65 & 114 & 96.6 \\
\hline Total & 328 & 12 & 87 & 30 & 77 & 206 & 62.8 \\
\hline
\end{tabular}

た症例は Cairo 及びその後の病勢分類の規準よりもあま いとりかたになつている。

即ち喉頭瀨は結節癩の全身症状が進行するに従つて多 くなり，重症例ではその $96.6 \%$ に喉頭瀬が認められた。 斑紋瀨及び神経瀨に打ける喉頭の罹患率は Table 3. の如くで，斑紋獺 129 例の中の 7 例， $5.4 \%$ に会厭軟骨 部に知覚麻瘏を伴つた㬗漫性の強い発赤と軽度の腫脹を 認めた。これらの症例は顔面その他の皮夙に結核様玟綮 を有し，鼻粘膜にも biopsy によつてッベルクロイドの 変化を認めたものであつて，喉頭の会厭軟骨部に生じた 発赤腫脹も結核様斑紋によるものと考えられる。な打 1 例は会厭軟骨部に狼瘡に類似した潰瘍を有し，この部位 の biopsy 及び動物試験によつて結核様瀨変化であると とを証明したものである。

神経瀨では喉頭神経麻瘒に因る変化（声带の運動障 碍）を 133 例の中の 12 例， $9.0 \%$ に認めた。

(b) 発病時期

㸊の発病後幾年で喉頭が侵されるかについては, Masini は皮唐に獺変化が現われてから数週後に喉頭が侵さ れるといい, Hillis, de la Sota, Bergengrün 等によると 発病直後から数年乃至 10 年までに罹患すると記載され ている。田中は声音障碍を有する 29 例について，持続 的㖽声の起り始めた時期を調査して, 次の如き成績を得 ている。発病後 $1 \sim 5$ 年: 4 例, 5 〜 10年: 18例, 11
Table 3. Rate of the involvement of larynx in tuberculoid and neural cases

\begin{tabular}{|c|c|c|c|}
\hline & Tuberculoid & Neural \\
\hline \multicolumn{2}{|c|}{ Number of cases examined } & 129 & 133 \\
\hline \multirow{5}{*}{ 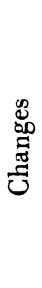 } & Tuberculoid changes & 7 & 0 \\
\hline & Paralysis of recurrens & 0 & 4 \\
\hline & Paralysis of posticus & 0 & 5 \\
\hline & Paralysis of internus & 0 & 3 \\
\hline & Ulceration & $1^{*}$ & 0 \\
\hline \multicolumn{2}{|c|}{ Number of cases involved $(\%)$} & $7(5.4)$ & $12(9.0)$ \\
\hline
\end{tabular}

* Tuberculoid changes were noticed on biopsy in the epiglottis which showed intensive hyperaemia. swelling and ulceration at its upper rim.

15年：6例，16年：1例である。

私は喉頭の 1 小部分に比較的新鮮な浸潤または結節が 限局し，他の部位にはまだ臨㕅的に賴变化が証明できな 、軽症喉頭瀨 84 例（喉頭の変化が軽度です陳旧のもの と癩の発病時期が明確でないものは除外した）について 癩発病後の経過年数を調査して，Fig 1. (a)の如き成績 を得た。

これによると，喉頭は発病後 6 年までに羅患するもの 
Fig 1. Years elapsed from the onset of leprosy to the manifestation of initial symptom in the larynx, huskiness and of dispnoea.

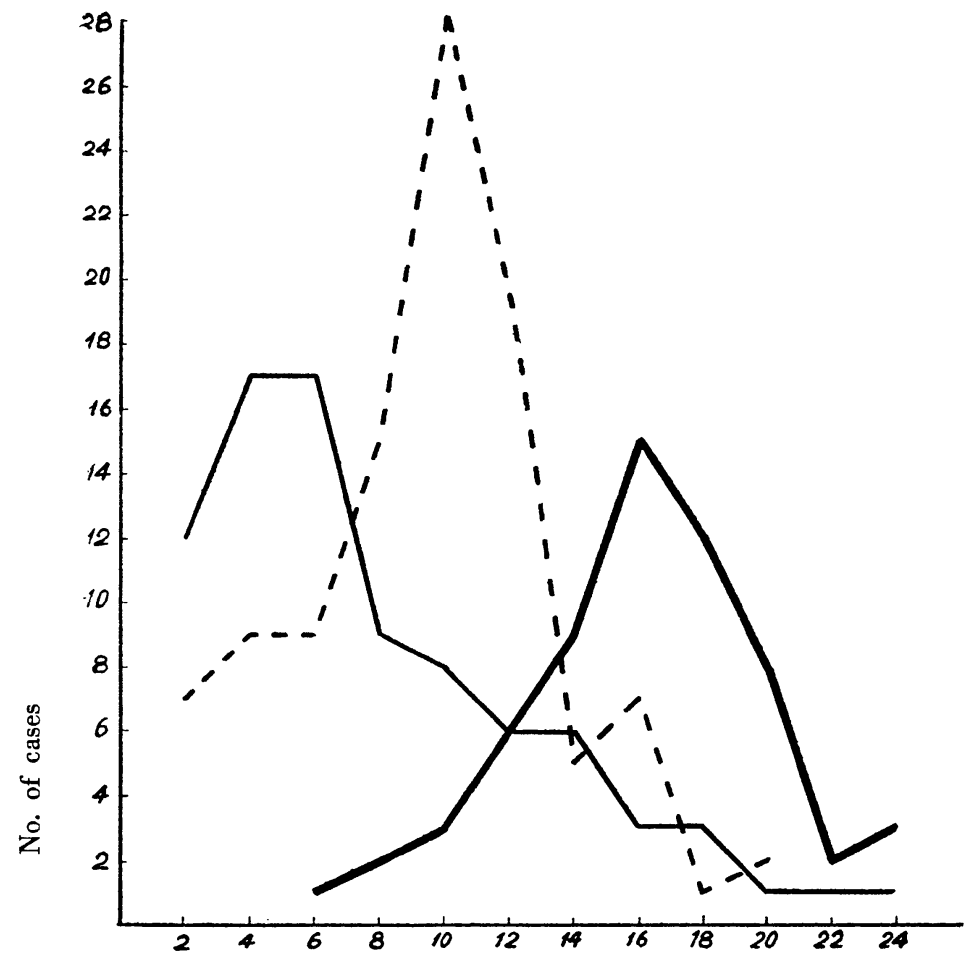

Years after onset of leprosy

Note :

(a) Manifestation of initial symptom in the larynx

(b)

(c) " dispnoea

が最も多く, 46例, $54.8 \%$, 以後急に減少している。

(c) 好発部位i

Bergengrün, Glück, 田中は会厭軟骨部殊にその遊離縁 が最もしばしば且つ最も早く罹患し，次で披裂会厭嫂譬 に好発し, しかる後にこれらの部位から喉頭内腔に拡が ると述べている。Gerber あ最初に且つ主として侵され る部位は喉頭入口部ですり，罹患部位は囊状腺分布区域

(Balgdrüsenregion) であるとしている。

私は軽应喉頭瀨の 98 例について罹患部位を検査して，

Table 4. の如き成積を得た。

会厭軟骨部が瀨の最も好発する部位であるととは諸家 の統計に一致し，しかも，軽症例についての所見による

と, 例外なく病変は会厭上緣部に始まつている。 披裂軟骨部は会厭とともに侵されるととが多いが，8 例は会厭部に変化なく披裂部にのみ病変を証明したもの でめる。即ち軽症喉頭瀨の全例に括いて喉頭入口部の何
Table 4. Parts of predilection in the larynx for lepromatous involvement (examined in 98 cases of the light laryngeal leprosy)

\begin{tabular}{|c|c|c|c|c|c|c|c|}
\hline & 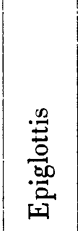 & $\begin{array}{l}\stackrel{0}{0} \\
\stackrel{0}{0} \\
\frac{3}{4}\end{array}$ & 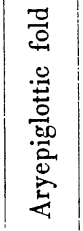 & 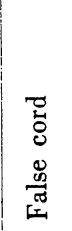 & 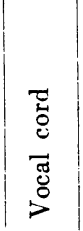 & 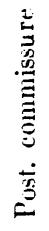 & 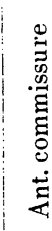 \\
\hline No. of cases & 90 & 47 & 15 & 13 & 23 & 0 & 0 \\
\hline$\%$ & 91.8 & 48.0 & 15.3 & 13.3 & 22.5 & & \\
\hline
\end{tabular}

処かに癩病変を認めたのであつて，瀨の好発部位は喉頭 入口部であるといらととができる。喉頭内腔では声带に 変化を見る場合が多く $(22.5 \%)$ ，連合部と 声門下腔と は罹患し難い部位と考えられる。重症喉頭麻 176例につ 
いて検宣した成精によると，会厭部 $100 \%$ ，披裂部 90.9 $\%$, 仮声带 $7.4 \%$, 声带 $71.0 \%$, 後連合 $8.5 \%$, 前連 合 $1.1 \%$ に瀨変化を認めた。

てれさ要するに，喉頭に抢ける瀨の初発部位は主とし て喉頭天口部で, 就中会厭軟骨部でめる。喉頭内腔では 声带及び仮声黄に好発するが，との部位は多くの場合入 口部よりもゃや抢くれて罹患する。

喉頭に潰瑒を認めたものは 460 例中の 43 例， $9.4 \%$ で 鼻腔に比して甚だ稀であるが，乙れを部位的にみると， 会厮部の辺縁 31 例, 舌面 9 例, 内面 8 例, 拔裂部 17 例 仮声带 3 例 声带 5 例で，会厮部の辺緣仔発する。

\section{3. 症候について}

\section{A. 注慗}

喉頭に扎けるッベルクロイドの变化は局所粘膜の知覚 麻疾と軽度の腫脹を伴つた発赤としてあらわれ, 発赤は 結節濑性浸灌に比して一般にやや明かるい色調を打びて いる。私つ経験した症例は 1 例を除いて会厭軟骨部乃至 喉頭入口部に限局して上記の変化が認められたが，健康 部との境界は明確でなく，乙の点皮㲊に見られる結核様 斑紋とは現われかたが著しく異つている。鼻粘膜に生じ たツベックロイドるやはりその境界ははなはだ不明瞭 で，一見急性鼻炎に類似した所見を呈するすのであつ た。

な托 I例に扎いては会厭軟骨上縁部に黄白色の壊死性 物質を附着したやや深い、潰洗を形成し，左側の仮声带も 表面凹凸呈して強く発赤腫脹したものでめる。

喉頭のツベルクロイド変化はいずれる顔面にツベルク ロイド型湠祾を有する症例に見られ，且つ同時に鼻腔粘 膜にも同様变化が認められた。

B. 結 節 瀨

(1) 追覚症

(1) 埕頭内つ乾懆感：Gerber, Dorendorf は初期に乾 燥性喉頭炎の症状が久しく持続するといつているが，私 はとの種の症例に遭遇したととはなかつた。

(口) 声音障碍：声音障碍は獺の診断の 主要症候とし て古くから知られていた。わが国では令義解に「或語声 嘶変」つ記載があり，外国では Theodoricus (1526) が 鼻声, 声音粗雑, 無響音の扎てることを記し， A. Bachuone は患者に歌わせて，とわね（Stimmklang）を検 查せよと記している $\left(\right.$ Gerber $\left.{ }^{4}\right)$ )。Leloir は初期の症候 として Belegtsein der Stimme を記載してから, その後 の文献にはこれを引用するものが多い。

比較的早期の結節瀨についての私の観察によると, 初
発後皮病病変が全身化する時期になると，上気道粘膜の 全域にわたつて発赤と浮腫様の腫脹を伴つた軽い、浸潤を 来たすすのが多い。そして，乙の時期に軽度の嗄声を訴 える場合が多い。しかし，との場合の㖽声は一過性のも のが多く，数週〜月余を経て恢復するのが常である。

持続的の嗄声が起るのはとれより更に数年の後である が，持続的声音障碍の起つた時期の明かな 102 例につい て櫴発病からの経過年数を調查した結果, Fig 1. (b) の 如き曲線を得た (Fig 1. 参照)。

とれを見ると，発病後 9 〜 10 年で起つたものが 28 例 で最も多く, 11 12年が 19 例， 7 〜年が 15 例でてれ に次ぎ，その前後は急激に減少する。即ち結節瀨の発病 後 7〜12 年を経過する間化約 $61 \%$ が声音障碍を訴える にいたつている。

嗄声の程度は初め belegte Stimme であるが，多くの 場合， $3 \sim 4$ 年の間に増強し，遂に失声状態となるに至 る。しかし，経過中に病变部が吸収軽快して，失声状態 に至らないで停止乃至恢復するものも少くない。

(ヘ) 呼吸困難：喉頭の病変が高度になると，喉頭に 狭窄を起して呼吸困難を訴えるものが多い。呼吸困難の 起る時期については，田中が声音障碍より気管切開をで の期間を 7 例について調查し， 6 カ月 1 例， 1 年 2 例， 2 年 3 例, 7 年 1 例の成績を発表しているほか記記載を 見ない。

私は気管切開の 53 例と現在比較的軽度ながら呼吸困 難を挀えている8例, 合計 61 例について, 㿎発病から 呼吸困難出現までの経過年数を調查して，Fig 1.(c)に示 す曲線を得た (Fig 1，参照)。

これを見ると，発病後 $15 \sim 16$ 年のものが 15 例で最も 多く, 17〜18 年のもの 12 例, 13〜14 年のもの 9 例で, 以下その前後に大体同様な曲線をえがきつつ減少してい、 る。

な打呼吸困難と嗄声との関係については, 殆んど全例 が高度の嗄声即ち殆んど失声状態にあり，との状態にな つてから凡そ $1 \sim 2$ 年後に呼吸困難を訴光始めるものが 多い。

（2）他覚的症候

(1) 初発症状：Zwillinger u Läufer, Masini は初期变 化乃至前駆症として, 喉頭粘膜の発赤, 腫脹, 粗鬆化, 分泌過多, 瘙㾕感をたは異物感を訴え, 充血は数日一数 週後に消退して，その後著明な粘膜の乾懆を来たし，光 沢を失い，ラック様の外観を呈すると述べている。Gerber はこの乾燥性喉頭炎が倠一の初期症状として年余に わたつて持続すると述べている。 
私は頖発病後 1 年内外の患者について検査し, 鼻腔に

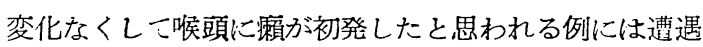
しなかニたが，鼻腔に瀨の初期変化を有する 21 例中の 14例に。碝頭にも初期变化と認むべき発赤, 腫脹を認め た。

この症状は一見急性喉頭炎に似ているが，粘膜の発赤 は喉頭全般にわたるるのは少く, 主として会厭軟骨部と 披裂軟骨部に限局し，内腔では主として声带に限局して 認められる。発赤の色調を詳細に観察すると, や中紫赤 色の色調を扎び，粘膜表面の発赤はむしろ軽度で，粘膜 の染層に強度の充血のあるととを思わせる。

発赤とともに浮腫様の外観を呈した軽度の腫脤を伴 ら。しばしば, 発赤は軽度で浮腫様の腫脹が主な変化で あるととがある。

発赤, 腫脹は会厭部の上縁に強く, 時として舌面, 喉 頭面にも見られる。同時に披裂軟骨部にも同様の变化が 見られるととが多い。1 例に披裂軟骨部の軽度の運動障 碍即ち発声時の内転運動が迅速を欠くのを見た。

声帯には強い発赤を生ずるととは少く, 一様にバラ色 を呈して肥厚し，遊離縁が厚ぽつたく，丸みを呈するも のが多い。仮声带に発赤腫脹を認めることは少い。

分斑物の増加及び Gerber 等のいう乾懆性喉頭炎の所 芫は見られなかつた。しかし発赤腫脤の割に分必物はむ しろ僅かである。

僅かに1例において声带表面の乾懆した所見を認めた。 声带の腫脹したものは軽度の嗄声 (belegte Stimme) を訴えるが, 持続的なるのではなく, 数カ月後には全く 正常に復する。

（可浸潤及び結節形成：初期应候としての発赤腫腿 に続いていかゆる顧性浸潤或いは結節が発生するととは 殆んどない。一旦発赤腫脹が消失し，数カ月〜数年を経 て徐々に浸潤性肥厚或いは結節が見られるのが普通であ る。しかし，時として急性症状を伴つて浸澗，結節が多 発するとともある。

皮店に扔いてもえらであるが, 鼻腔, 咽頭, 喉頭にも 浸潤を主とするものと結節形成を主とするすのとがあ る。

喉頭では結節を以て顆変化が初発したと思われるすの は少い。しかし，発病後長年月を経過した陳旧結節瀨で は，喉頭の一部に結節をつくつて発病するものが少くな い。この所見は咽頭に扎いても同様に見られる。これは 発病当時に出現した浸潤がその後殆しど吸収せられ，臨 床的には一見正常のような状態に恢復した部位に, 再び 顆病変が起つた場合に見られる所見と考えられる。
浸润性肥厚は喉頭入口部に好発し，会厭及び披裂会厭 䀛譬が高度の浸潤のために原形を全く消失して，喉頭鏡 下に輪状の空気枕を見る如き変形を呈する場合がある。 また会厭軟骨部が浸润性肥厚のために $1 \mathrm{~cm}$ 位の厚さを呈 するとともさ䚾ど稀でない。

湎漫性浸潤部は表面平滑, 乾燥し, 譄様の外锶を呈す る。喉頭入口部の高度に肥厚した部位にはしばしば白 色乃至乳白色の Leukoplakia を形成するととがある。

喉頭に生ずる灀結節は粟粒大乃至小豆大が普通で, 初 めは淡紅色, 後には黄白色を呈して硬い。この点は他の 粘膜に打けるものと变りがない。稀に示指頭大の結節を 会厭部舌面, 披裂部内面に見るととがある。

結節の好発部位侩厭軟骨部上縁, 披裂内壁, 仮声带 及び声带である。喉頭入口部にはしばしば結節が密生し て珠数状を呈するととがある。結節の表面と周囲には初 め発赤と血管の怒張を認めるととが多い。

披裂軟骨部の上面には小豆大～小指頭大の楕円形の丘 疹を形成するととが少くない。との変化はする程度浸潤 を来たした後に生じ，左右対称性に生ずるととが多い。 淡聎色乃至やや赤みを打びた乳白色を呈し, 中央部に軽 い凹夕を有する。との丘疹はこの部に永く限局し, 抎大 する傾向は少い。表面は容易にびらん丈は浅い、潰瘍面を つくるが，梁達する傾向はない。通常との周田に著明な 紅暈を有する。

粘膜斑（Plaques muqueuses）を見るととも稀でない。 披裂軟骨上面及び内面, 後連合にわたり形成される。

(4) 潰瘍形成：Schrötter, Sokolowsky u. Blohmke, ${ }^{12}$; Salzberger は喉頭には潰瘍を形成するととがないとして いるが，Virchow（1885）は喉頭内に濑性深達性潰瘍を 有する剖検例を供覽した。de la Sota, Masini, Gerberは 潰愓は極めて稀であるとし，その理由として, Gerberは 喉頭の病变部は潰瘍をつくるととなく徐々に症痕を形成 し, 或いは喉頭の潰瘍は直ちに治瘾するためでめろうと した。田中も喉頭の浸潤は崩壊するととなく, 直ちに洀 痕性収縮をいとなむものが多いと述べている。

私の 460 例の喉頭獺の観察では, 43 例, $9.4 \%$ に潰瘍 を認めた。その好発部位については前述した（Tab) 1. 参照)。

表在性のびらん性潰瘍を形成するととが多いが，会厭 部に生した潰瘍は深部組織を破壊して, 軟骨を露呈する 場合が少くない。会厭部の舌面や声带に生じた結節に は, 稀にその中央部に噴火孔状の潰瘍を形成しているの を認めた。

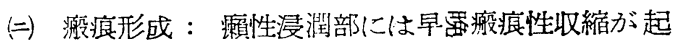


つて, 薙頭の 1 部が牽引せられたり, 瘾着が起つたりし て，種々の変形，狭窄を招来する。

会厭軟骨部の変形は特異で且つ喉頭瀨の後期の庁状と して最もしばしば見られる。

会厭部の浸潤がある程度進行すると，この部分の運動 が障碍せられ，初めは高調音の発声時には軽度挙上する が，後には全く不動性となり，喉頭入口部を打抢うよう に傾斜したます固定して，喉頭鏡㭘査を著しく困難なら しめる。しかも浸潤部は著明に硬固となり，会厭挙上器 をかけても内腔の観察が不能に扔わるととが多い。会厭 部に瘢痕性収縮が起ると, 会厭体部にくびれを生じて辺 縁が喉頭面に巻き込み，オメガ状を呈するととが多い。 更に強い収縮によつて，会厭軟骨部が著明に短縮して， 一見その大半を消失したと思われる所見を呈する場合も 少くない。

会厭部とともに披裂会厭貱壁の収縮が起ると，喉頭入 口部に強度の狭窄を来たす。しばしば鉊筆太位の狭窄が 起り, 気管切開後には更に強い収縮が起つて, 消息子を 辛うじて通し得る程度の高度の狭窄も起る。

声带と仮声带とは 1 個の硬い浸潤乃至疲痘組織と化し て，鑑別が殆んど不可能となる場合が多い。或いはなた 叫頭内腔の強度の浸潤性肥厚の部分に瘢㾗性収縮が起つ て，喉頭内腔が円筒状乃至漏斗状に狭窄する場合も稀て ない。声門が 1 小孔と化す場合もあり, 声門の上部或い は下部で疫痕性隔膜形成も見られた。

(ホ) 喉頭局部に招ける変化：

（i）会厮軟骨部 この部位は最夜に且つ最もしばし ば侵されるところである。 Bergengrünは総ての場合会 厭部が最初に罹患すると述べているが，私の軽症喉頭獺 90 例についての観察によると，前記した如く90 例は会 厭部に 8 例は披裂部に初発したものであつた。

会厭部に打ける初発病单はその遊離縁の発赤腫脹をも つて始まる。

結節は辺縁部のやや舌面に移行した部位で，正中線よ りもやや左右に偏して初発するのが常である。

澒漫性浸潤与辺縁部に初発し，最初は左または右に偏 在して変化が強度である。浸潤は舌面の上部にも㹡がる が，喉頭面に強く起るのが常でもる。

（ii）披裂軟骨部との部の浸潤，結節については前 述した。浸潤性変化がやや著明になる頃になると，との 部の運動障碍が見られるととが比較的多く，初めは発声 時の内転運動が痋れる程度であるが，後には全く不動性 になるすのが多い。
肥厚した披裂部は早晚瘢痕化して，表面がなめし皮様 となり，しばしば，後連合部とともに左右が 1 本の馬蹻 型の痽痕組織と化して，原形を完全に消失するようにな る。

(iii) 喉頭内腔 喉頭内腔の病変は入口部から連紩的 に進展するといらすのが多いが（Glück，Bergengrün, 田中）私の観祭によると必ずしもそうではない。喉頭瀨 の初期に，すでに声带に発赤腫脹を見るととについては 前述したところでめる。仮声带に変化がなくて，声带に 結節，浸潤を見る場合も稀でない。

声带には結節を形成するととが比較的多く，全長にわ たつて粟粒大〜麻実大の結節が多発する。声带に打ける 結節の好発部位については未だ記載がない。声帶の一部 に小結節を認めた 12 例について，声带を前，中，後部 に区分して，結節の発生部位を分けると

前部と中部の境界附近に発生………....8 例

中部之後部の境界（声带突起附近）……3 例

前, 中, 後部の境界……………....... 1 例

これでみると, 声带で最も強い運動を行ら部位に初発 しやすいと考えられる。

声带に高度の浸潤が起ると，表面平滑を欠き小さな山 凸を呈するととが多い。声带下部に肥厚が起つて声門の 狭窄を来すととがもるが，とのよらな例はむしろ稀でせ る。

仮声带は瀮漫性に浸潤, 肥厚するのが常であつて, 結 節形成は比較的稀である。浸潤が強くなるとモルガン氏 管入口部を狭窄し, 声带と仮声带とは 1 の肉塊と化し て，喉頭鏡下での鑑別か洇難となる。

披裂軟骨部内面の浸潤は連続的に仮声带に拡がり，会 厭内面の浸潤と相をつて喉頭上腔を狭くする。との部の 瘢痕性収縮のために，喉頭内腔の前後径はしばしば強く 短縮し，喉頭鏡下で声带が著明に短く見えるのが注意を ひく。

声带の運動障碍はさほど稀でない。内腔にまだ病変を 認めない軽症のものには運動障碍が起らないが, 明瞭な 浸潤が見られる頃になると声帯の運動障碍が起る。初め は声帯の外転運動範用が制限されて声門は屍体位以上に 開大しなくなるが，声带の内転運動は正常かやや紝漫で ある。しかし, 高度なものでは僅かに裂隙状の声門をの こして, 肥厚した声带が正中位乃至副正中位に固定せら れて廻帰神経麻瘨の像を呈し, 高度の呼吸困難を訴える ものが少くない。多くの場合, 声带は正中位で両側が緊 密に接着しているよりも，副正中位に固定し，裂㗂状の 間隙を通して困難ながら呼吸しているものが多い。声带 
の開大運動は全く不能で, 強い吸気をやらするとしばし ば却つて声門が狭小する所見が見られる。

声带の運動障碍の原因については, 局所の喉頭筋の瀨 性浸潤，披裂関節の硬化などによるものか，または下喉 頭神経の瀬性麻渒によるものかの決定は困難でめるが, 私は少くともその大部分は神経麻疩に因るものと考え る。

多数の剖検例について, 喉頭の病変と上, 下喉頭神経 の变化とを病理組織学的に検索した結果, 両神経ともし ばしば高度の瀨性変化を起しているのを認めた。上喉頭 神経には軽症喉頭癩に括いても殆んど毎常病変が見ら れ，下喉頭神経には重症喉頭顆の殆んど全例に高度の病 变が証明された。この所見と喉頭鏡所見とから, 重症喉 頭瀬に打ける声带の運動障碍は喉頭神経の顆性麻源に因 るものですろらと考えられるのである。

\section{4. 喉頭癩による呼吸困難の原因について}

知頭顀による呼吸困難はその大部分 $(72.1 \%)$ が瀨㙏 病後 13〜20 年を経過したりのに起る (Fig 1. 参照)。

呼吸困難の原因については, Leloir は喉頭の浸潤部に 浮腫を伴つたときに起るといい，Bergmann は腫脹が声 門または喉頭下腔に漫延したときに起ると記している。

田中はこれに反してて, 浸潤期を過ぎて般㾗性收縮が起 るときに現かれるすのが多いと主張している。

私が気管切開を施行した患者で, 手術前に喉頭内の所 見兴明確にするととができた应例は 20 例であるが，乙 れについて狭窄部位をみると次の如くである。

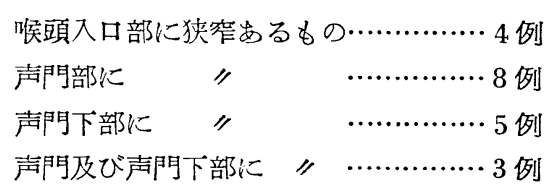

即ち呼吸困難の原因は入口部の狭窄によるよりも, 内 腔の狭窄によるものが遥かに多いととがわかる。しか も，入口部に狭窄める4例はいずれる殆んど失声状態の 高度の声音障碍を訴えて抢り, 内腔の観察は入口部の狭 窄のために不可能でめつたとはいえ, 恐らく声門部の浸 潤が強かつたととは否定できない。

声門の狭窄は声带の浸潤性肥厚によつても起るが，乙 れだけでは呼吸困難は概して軽度でめる。気管切開例の 多くは声門の開大運動が障碍されるに及んで初めて高度 の呼吸困難を訴えたものである。

これを要するに，喉頭㸊に打ける呼吸困難は喉頭入口 部の狭窄に因るものは少く, 喉頭内空の浸潤性肥厚に加 らるに迴帰神経の顀性变化に因る神経麻疩に原因するも
のが多いと考える。な抗ととに興味を感ずることは，呢 頭鏡下で相当度の狭窄が認められるにかかわらず, 自覚 的にはそれほどの呼吸困難を訴えないものが少くないと とでめつて, 獺の如き極めて慢性の経過をとり, 長年月 を要して徐々に狭窄が起るすのでは, 狭い気道による呼 吸に相当度まで慣れ得るすのであると思われる。

\section{5. 経過について}

㗱頭に癩変化が起つてから, 声音障碍が起り更に呼吸 困難を訴えるに至るまでの時間的経過については, Fig1. (a)，(b)，(c)仁示す瀨発病よりの経過年数による曲線を照 合すれば明かになると思ら。

即ち瀬が発病して大体 3〜6年を経て唉頭に癩变化が 発生し㕸め, 更に $3 \sim 6$ 年の間に喉頭内の病变が進展し て声音障碍が起る。嗄声はその後 $3 \sim 6$ 年の間に次第に 増強して失声状態となるものが多く, かくしてやがて呼 吸困難を訴えるようになるのである。

軽度の呼吸困難が起つてから大体 1 年内外で気管切開 を施行するすのが多い。しかし，気管切開は大体に㧊い、 て, 温諼の季節には施行例が少く, 11月の寒冷の時期に はいつて呼吸困難が增強して手術しなければならなくな るものが大部分であつて, 気管切開は主として11月末 頃から 4 月頃までに行われている。この季節には上気道 の非特異性の急性炎疜が起りやすく, 喉頭内部に発赤腫 脹が加わり, 分必物が増加し, このために呼吸困難が急 に堌強するものと考えられる。

喉頭に打ける䘽病变も全身の皮膚症状などと同しく, ある程度病変が進展すると, 症状の停止または恢復の傾 向が見られる。初発症状は数カ月の後には発赤腫脹を消 退し, 更に年余を経て一旦吸収して, 臨床的には殆んど 顆性変化が認め難いまでに恢復するすのが少くない。し かし, 多くの場合, その後数年を経て来蔔する増悪期に 再び新病巣を形成し或いは旧病巣が再燃して, 病変が抎 大進展して症状が悪化する。かくの如くして, 永い経過 の間には, めるものは全身状態の好転とともに喉頭の病 変も著しく軽快して殆んど治瘾状態を呈するものがめ り, あるすのはまた更に増悪して, 呼吸困難, 気管切開 の転帰をとるものがめる。

喉頭全域に瀨病変が抎大しても，その終局は必ずしも 気管切開に至るわけではない。この中の多数の症例はむ しろ永い年月の中に病巣が吸収して, 疲痕性収縮を起 し，種々の变形をのとして停止乃至治瘾状態を呈するの が見られる。

ととに與味のあるととは, 気管切開後に上気道の病变 
が急速に洀痕化する傾向を示し, 数年の後に鼻腔, 咽 頭，喉頭の諸所に高度の癜㾉性収縮が起ることでめる。 局所のみならず，皮居にもこの傾向が見られ，気管切開 後に皮有の潰湟が急速に治虑した例が少くない。

喉頭の病変は気管切開の 後に影著な治瘾傾向を示す が，とれとともに入口部き内腔に瘢㾉性收縮が起つて, 気管套管を生涯插着したままでいなければならない症例 が多い。

一般に喉頭瀨による呼吸困難は瀨の末期の症候でめつ て, 私の統計によると, 気管切開後死亡までの年数は平 均 5 年である。もちろんとれはプロミンが現われない大 風子油時代の統計であつて, 現在に括いては喉頭瀨の臨 林殊にその予後忹全く一变している。

すでに述へた如く、気管切開によつて上気道を造断, 静置するととによつて, 上気道の病变は急速に吸収, 般 痘化の傾向を来たすが, 長期間の套管呼吸によつて, 更 に気管の梁部え瀨病変を進展させ, 数年の後にはその部 に狭窄を来たして再び高度の呼吸困難を訴え, 遂に等息 死の転㷌をとるものも稀に見られる。

\section{6. 総 括}

1）結節瀨 711 例についての喉頭の罹患率は $64.7 \%$ で 㿠朌の $93.2 \%$ に次いで高く, 重症患者 $\left(\mathrm{L}_{3}\right)$ ではその $96.6 \%$ の高率に喉頭瀨を認めた。

2）斑紋顆 129 例の中の 7 例 $(5.4 \%)$ に喉頭に発生 した結核様斑紋の変化と思われる所見を認めた。而して その 1 例について biopsy と動物試験を行い結核様攧の 变化であるととを確かめた。

神経瀨 133 例の中の 12 例 $(9.0 \%)$ に喉頭神経麻㯅に よる声带の運動障碍を認めた。

3）結節㸊に扔いては，発病後 6 年までにその $54.8 \%$ が喉頭瀨を合併し，10年までに $75.0 \%$ 侵される。

4) 喉頭瀨の好発部位は会厭軟骨部の上緑でめる。

5）発病後皮夙の病変が全身化する時期に，喉頭にも 発赤腫脹を来たして声音障碍を訴える場合が多いが, 月 余を経て恢復するのが常であり，発病後 7 12年を経る に及んで持続的の嗄声を訴える場合が最も多い(61\%)。

6) 喉頭瀨の初発症状は会厭軟骨部之披裂軟骨部に,

時として声帯にも, 限局した発赤腫脤を呈し, 発赤の色 調はやや赤紫色を打び, 粘膜の染周に強度の充血のある ことを思わせ且つ発赤ととるに浮腫様の外観を呈する。 声带には強い発赤か起るととは少く, 一様にバラ色を呈 して肥厚するものが多い。

7）結節は会厭軟骨部上縁，披裂軟骨部及び声带に好
発し，入口部にはしばしば結節が坤数状に密生才ること がもる。声带に発生する結節は発声時に最も強、渾動す る前 $1 / 3$ と中 $1 / 3$ の境界部に初発することが多い。

披裂軟骨部の上面には左右対称性に小豆大一小指頭大 の棈円形の丘疹を形成するととが少くない。淡挑色或い はやや赤みを打びた乳白色を呈して，表面は容易にびら ん又は浅い潰瘍をつくるが，この部に限局し，菘大する 傾向を示さない。

8）滩漫性浸潤は会厭軟骨部に好発し，後には会厭及 び披裂会厭蚾襞が原形を全く消失して，喉頭鏡点: :輪状 の空気枕を見る如き変化を呈するととが多い。

喉頭入口部の高度に肥厚した部位にはしばしば Leukoplakia を形成する。

披裂軟骨部から後連合にかけて粘膜班(Placiues mu queuses）を形成するととが稀でない。

9）喉頭に㸊性潰瘍を認めた症例は少く，9.4\%でも る。潰璄は一般に表在性であるが，会厭軟骨部つ辺縁に できたものは墚部組織を侵し，軟骨をも破摆する場合が 少なくない。

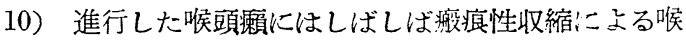
頭の変形，畸形或いは狭窄が見られる。

11）重症の喉頭顧には声带の運動障碍がしけずしげ見ら れる。初めは声带の外転運動の範囲が縮小され, 高度の ものでは廻帰神経の全麻痺の像を呈する。

声带の運動障碍の原因については, 局所の滨頭筋の渡 潤或い梳披裂関節の硬化によるものか，または廻㷌神経 の制性麻源によるものかの決定は困難でるるが，私の剖 検例についての病理組織学的検索によると，その原因は

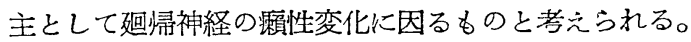

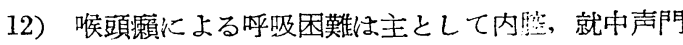
部の浸潤によつて起り，廻帰神経の麻瘁症状が合汧する と急激に增強する。

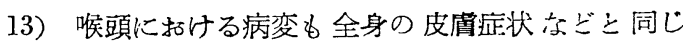
く, ある程度病変が進展すると,やがて症状つ停止また は恢復の傾向を示すが，しかし，多くの場合，その後数 年のらちに旧病栄の再燃, 新病巣の形成が起つ下増悪す る。以上のような経過をくりかえしながら病変は次第に 増進するのが常でむる。

14）喉頭は瀨発病後大体 $3 \sim 6$ 年で罹患し, 更に3 6 年の間に声音障碍が起り, 更に $3 \sim 6$ 年さ経て失声状 態，呼吸困難を招来する。

15）喉頭のみならず上気道の病变は気管切開後に著明 な治瘾傾向を示し，その結果しばしば強い瘦瘨性収縮を 招来する。 
16）ととに記載した成績は化学療法以前のものであつ て, 従つて現今汇ける喉頭獺の臨床とは打もむきを異 にするものがあると思われる。

\section{文献}

1) Bergerrgrün: Die leproese Erkrankung d. Nase, d. Rachens u. d. Nasenrachens, d. Larynx u. d. Trachea. Heymanns Handb. d. Laryngol. u. Rhinol. 1898

2) do.: Ein Beitrag zur Kenntnis der Kehlkopflepra. Arch. f. Laryngol. u. Rhinol. 2, 1895

3) Dorendorf, H. : Ein Beitrag zur Lepra der oberen Luftwege. Arch. f. Laryngol. u. Rhinol. 16, 1904

4) Gerber, P. H. : Beitraege zur Kenntnis der Lepra der oberen Luftwege u. der Verbreitung der Leprabazillen. Arch. f. Laryngol. u. Rhinol. 12, 1902

5) Glück, L. : Die Lepra der oberen Atmungsu. Verdauungswege. Mitteil. u. Verhandl. d. internat. wissenschaftl. Leprakonf. in Berlin. 1897

6) Klingmüller, V.: Die Lepra Jadassohns Handb d. Haut u. Geschlechtskht. 10/2 1930

7) 大内長一郎・吉田太助 - 山口晴策：聴器並に上 気道に於ける癩性変化 日新医学 第 19 年, 7 , 昭 5
年

8) Pinkerton, F. J.: Leprosy of the ear, nose and throat: Observations on more than 200 cases in Hawaii. Arch. Otol. 16, 469-487, 1932

9) do. : Leprosy of the upper respiratory tract. J. A. M. A. 111, 1437-1443, 1938

10) Salzberger, M.: Die Lepra der oberen Luftwege u. des Ohres in Palaestina u. Cypern. Mschr. f. Ohrenhlk. usw. 62 Jg. 1928

11) Sokolowsky, R. : Lepra Denker u. Kahlers Handb. d. Hals-Nasen-Ohrenhlk. 4, 1928

12) Sokolowsky u. Blohmke: Die Lepra d. oberen Luftwege u. d. Ohres. Zschr. f. Larỵnol., Rhinol. u. ihre Grenzgebiete, 11, 1923

13）田中文男：気道の癩性变化に就いて 日新医学 第 5 年, 6,7 , 大正 5 年

14) 田尻敢：呼吸器の瀨 レプラ $5,4: 6,5$, 昭 和 9,10 年

15) Virchow, R.: Demonstration v. Lepra laryngis. Berl. Klin. W. 12, 1885

16）義江義雄：上気道瀨 レプラ 18，2，路 24 年

17）：：瀨性喉頭性呼吸困難 レプラ, 23,2, 昭和29年 